\title{
JURIDICAL REVIEW OF THE FACILITATION OF COMMUNITY PLANTATION DEVELOPMENT BY PLANTATION COMPANIES
}

\author{
By : \\ Lestariana Marwassari, Yamani, Emelia Kontesa
}

\begin{abstract}
The government regulates the facilitation of community plantation development as much as $20 \%$ of the area of rights by plantation companies. This provision which is the obligation of the company was still not regulated in a clear and firm legal arrangement so that it created multiple interpretations in its application. Based on this matter, the writer was motivated to analyze the legal arrangements for the facilitation of community plantation development by plantation companies and the obstacles encountered in the implementation. The plantation company which was the focus of the research was PT. Pamor Ganda with Business Right (known as $H G U$ in Indonesia abbreviation) Number $16 / 1989$ by studying the $H G U$ extension document. This was a normative research with a statutory approach. The method of analysis performed was content analysis, then the interpretation was carried out to understand the conclusions. The results showed that legal arrangements in the land sector, Micro, Small, Medium Enterprises (MSMEs), and plantations had not been able to solve the problems that exist in the implementation of facilitation of community plantation development by plantation companies. The company's obstacle was that the plasma farmers' plantation area around the companies' plantation area had not been able to meet the $20 \%$ area requirement. While PT. Pamor Ganda had fulfilled its obligation to facilitate community plantation development by releasing its 114 hectare of $H G U$ area.
\end{abstract}

Keywords : Facilitation of community plantation development, $H G U$ extension, plasma farmers 


\section{A. INTRODUCTION}

\section{Research Background}

Business Rights (hereinafter will be referred as $H G U$ ) is a type of land ownership rights regulated by the state. Regarding agrarian reform, apart from being a way to keep economic inequality around the plantation area from widening, as well as to improve the welfare and prosperity of the community, the government regulates the facilitation of community plantation development by plantation companies. According to Kartasapoetra et al, land has a social function, meaning that there must be a balance between the interests of individuals (owners, rulers, tenants) with the interests of society and the state. ${ }^{1}$ This is stated in the laws and regulations in the plantation sector and in the land sector.

The regulations issued by the government mean well, namely to build partnerships between plantation companies and communities. However, its implementation in the field still raises several obstacles and problems. This is due to the existence of legal uncertainty, confusion and multiple interpretations for the

${ }^{1}$ G. Kartasapoetra, et al. "Hukum Tanah Jaminan UUPA Bagi Keberhasilan Pendayagunaan Tanah", Rineka Cipta, 1991.p. 53 company, the Governor and the Regent/Mayor and other stakeholders. The regulations in one another and the implementation mechanism have not been clearly and firmly regulated. The interpretation of $20 \%$ of the plantation area facilitated is unclear whether the calculation is based on the area of the Plantation Business Permit or Business Rights. The existing regulation also does not state a solution if the area of plasma land around the plantation is insufficient to provide for the required and facilitated $20 \%$ area of plantation development.

The obligation to facilitate community plantation development by plantation companies is stated in Law Number 39 of 2014 concerning Plantations Article 58, Regulation of the Minister of Agriculture Number 98 of 2013 concerning Guidelines for Plantation Business Licensing Article 15, and Regulation of the Minister of Agrarian Affairs and Spatial Planning/National Land Agency Number 7 of 2017 concerning Regulations and Procedures for Establishing Business Rights Articles 40, 41 and 64. From the plantation sector regulations, it is stated that Plantation Companies that have Plantation Business Permits or 
Plantation Business Permits for cultivation are required to facilitate the development of community plantations around them by a minimum area of $20 \%$ (twenty per hundred) of the total plantation area cultivated by the Plantation Companies.

Whereas in the Regulation of the Minister of Agrarian Affairs and Spatial Planning/National Land Agency Number 7 of 2017 Article 40 states that $H G U$ holders are obliged to facilitate the development of community plantations around at least $20 \%$ (twenty percent) of the land area that is being applied for Business Rights for surrounding communities in the form of partnerships (plasma) in accordance with the permit from the authorized technical agency, for legal entity rights holders. This obligation to facilitate community plantation development is not only intended for the applications for new $H G U$ s because Article 64 of the Minister of Agrarian Affairs and Spatial Planning/National Land Agency Regulation Number 7 of 2017 states that Business Rights with an area of $250 \mathrm{Ha}$ (two hundred and fifty hectares) or more that were granted prior to this Ministerial Regulation and have not implemented a partnership (plasma land), are obliged to facilitate the development of community plantations in the vicinity of at least $20 \%$ of the total area cultivated by the owner of the land use rights, at the time of extension or renewal of rights.

Facilitation of community plantation development is a partnership between plantation companies and communities. In understanding this partnership relationship, we can review the legal arrangements in Indonesia regarding partnerships in the laws and regulations in the field of Small and Medium Enterprises. The legal arrangements to be analyzed are Law Number 20 of 2008 concerning Micro, Small and Medium Enterprises and its derivative regulations, namely Government Regulation Number 17 of 2013 concerning Implementation of Law Number 20 of 2008 concerning Micro, Small and Medium Enterprises.

To be able to analyze the barriers in implementing regulations regarding the facilitation of community plantation development, it is necessary to look at the implementation in the field. The writer focused on analyzing the 
facilitation of community plantation development from $H G U$ extension document Number $16 / 1989$ by $P T$. Pamor Ganda through document study. HGU of PT. Pamor Ganda ends on December 31, 2019, so that in the process of extending its $H G U$, the company must comply with the rules set out in Regulation of the Minister of Agrarian Affairs and Spatial Planning/National Land Agency Number 7 of 2017, one of which requires the facilitation of community plantation development.

\section{Identification of problems}

a. How were the legal arrangements for the facilitation of community plantation development by plantation companies?

b. What were the obstacles in the facilitation of community plantation development by $P T$. Pamor Ganda in the process of extending their $H G U$ ?

\section{B. RESEARCH METHODS}

This research used is a Normative Legal research, with Statutory Approach. Primary legal materials were based on article 7 of Law no. 12/2011 concerning the Formation of Legislation. The collection of legal materials were done through documentation studies, off line and on line literature searches. The analysis was carried out by content analysis, then interpretation was carried out to understand the conclusion.

\section{RESULTS AND DISCUSSION}

1. Legal Arrangements of the Facilitation of Community Plantation Development by Plantation Companies in Indonesia.

a. Laws and Regulations in the Land Sector

The legislation in the land sector that mention the facilitation of community plantation development is the Minister of Agrarian and Spatial Planning Regulation Number 7 of 2017 concerning the Regulations and Procedures for Establishing Business Use Rights. The regulation states that the first cultivated land use rights applicant with a cultivated land area of more than 250 (two hundred and fifty) hectares is obliged to facilitate the development of the surrounding community plantations at least $20 \%$ of the area of land applied for Business Use Rights for the surrounding community in the form of a partnership (plasma) in accordance with the business activity license issued by the 
competent technical agency, for legal entity rights holders. This obligation also applies to $H G U$ holders who have extended the $H G U$ and do not yet have a partnership in the form of plasma plantations.

In this regulation, other matters that are regulated regarding the Facilitation of Community Plantation

Development are the form of land rights application for plasma farmers who are involved in the partnership relationship, and the affirmation that even though there are no communities around the location of land use rights, the obligation as intended is still carried out by the holder of $H G U .^{2}$

$H G U$ holders who do not carry out facilitation for community plantation development will be subjected to sanctions in the form of written warnings, fines and/or cancellation of rights in accordance with the provisions of laws and regulations ${ }^{3}$. The period of imposition of sanctions from the

\footnotetext{
${ }^{2}$ Regulation of the Minister of Agrarian and Spatial Planning Number 7 of 2017 concerning Regulations and Procedures for Establishing Business Use Rights Article 41 paragraph (2)

${ }^{3}$ Ibid Article 57 paragraph (2)
}

first warning to the cancellation of rights is 3 (three) years and 9 (nine) months from the date of issuance of the warning letter.

b. Legislation in the field of Micro, Small and Medium Enterprises

Regulations Laws in the field of Micro, Small and Medium Enterprises (known as $U M K M$ in Indonesian abbreviation) are Law Number 20 of 2008 concerning Micro, Small and Medium Enterprises and Government Regulation Number 17 of 2013 concerning Implementation of Law Number 20 of 2008 concerning Micro, Small and Medium Enterprises. In this regulation, the $U M K M$ sector does not directly regulate the facilitation of community plantation development, but we can take the concept of partnership patterns and also the priority of partnerships between large businesses and $U M K M$ from this regulation in the $U M K M$ sector.

c. Legislation in the Plantation Sector The laws and regulations in the plantation sector are Law Number 39 of 2014 concerning Plantations and Regulation of the Minister of Agriculture Number 98 / Permentan / OT.140 / 9/2013 
concerning Guidelines for Plantation Business Licenses. The regulations regarding the facilitation of community plantation development that have been regulated in plantation regulations include:

1) Community plantations that are facilitated by entrepreneurs the plantation is outside the IUP-B or IUP area ${ }^{4}$.

IUP-B is a Plantation Business Permit for Cultivation, which is a written permit from an authorized official and must be owned by a plantation company conducting a plantation cultivation business. IUP is a Plantation Business Permit for Processing, namely a written permit from an authorized official and must be owned by a plantation company conducting industrial plantation business. Plantation Business can be carried out in all parts of Indonesia by Plantation Business Actors, according to the National,

${ }^{4}$ Regulation of the Minister of Agriculture Number 98 of 2013 concerning Guidelines for Plantation Business Licensing Article 15 paragraph (2)
Provincial, and Regency / City Plantation Development Plans.

2) The obligation to facilitate community plantation development considers: land availability; the number of families in the surrounding community who are eligible as participants; and the agreement between the Plantation Company and the surrounding community and the acknowledgment of the Head of the Provincial or Regency / City Service in charge of plantations in accordance with their authority. ${ }^{5}$

3) The surrounding community is eligible as a participant as such determined by the Regent / Mayor based on a recommendation from the local Camat; ${ }^{6}$

4) The obligation to facilitate community plantation development is carried out by utilizing credit, profit sharing and / or other forms of funding in accordance with agreements and laws and regulations. ${ }^{7}$

5) The implementation of facilitation of community

\footnotetext{
${ }^{5}$ Ibid Article 15 paragraph (3)

${ }^{6}$ Ibid Article 15 paragraph (5)

${ }^{7}$ Ibid Article 16 Paragraph (1)
} 
plantation development by companies receiving IUP-B or IUP is accompanied and supervised by the Governor or Regent / Mayor in accordance with the authorities covering planning, fulfilling obligations and business sustainability; ${ }^{8}$

6) Facilitation of community plantation development is carried out simultaneously with company plantation development and community plantation development completed within a maximum period of 3 (three) years $;^{9}$

7) Plantation companies that fail to carry out their obligation to facilitate community plantation development are subject to written warning sanctions 3 (three) times, each within 4 (four) months. If the 3rd warning is not fulfilled, the $I U P-B, \quad I U P-P$ or IUP is revoked and land rights are proposed to the authorized agency to be canceled. ${ }^{10}$

In regulating the facilitation of community plantation development, seen from the regulations in the land and plantation sector, there are differences including: First, regarding the arrangement of the area of $20 \%$ of community plantation development whether it is in accordance with the area of the Plantation Business Permit or based on the area of the $H G U$. Plantation regulations have a higher level because they are in the form of Laws but are not the same as Ministerial regulations issued in the land sector. The second is regarding the sanctions given to companies that do not facilitate the development of community plantations, both the timing and mechanism of sanctions are not the same between plantation regulations and land.

In Table 1 . below are the problems found in the implementation of facilitation for community plantation development by plantation companies and an analysis of the solutions that can be given.

\footnotetext{
${ }^{8}$ Ibid Article 16 paragraph (6)

${ }^{9}$ Ibid Article 40 verse (1) letter $\mathrm{f}$

${ }^{10}$ Ibid Article 51
} 
Table 1. Facilitation Problems for Community Plantation Development and Analysis of Solutions that could be provided

\begin{tabular}{|c|c|c|}
\hline No & Problems & Analysis of Solutions \\
\hline 1. & $\begin{array}{l}\text { The } 20 \% \text { area was allocated for } \\
\text { facilitation of community } \\
\text { plantation development, whether } \\
\text { it was in accordance with the } \\
H G U \text { area or the } I U P-B \text { area or } \\
\text { not }\end{array}$ & $\begin{array}{l}\text { The } 20 \% \text { area was adjusted to the } H G U \text { area } \\
\text { because: } \\
\text { a. In Ministry Regulation of } A T R \text { / } B P N \\
\text { Number } 7 / 2017 \text { the } H G U \text { application did not } \\
\text { require facilitation for community plantation } \\
\text { development but did not require the existence } \\
\text { of an Agricultural Business License for } \\
\text { Cultivation (IUP- } B \text { ), other than that, the } \\
H G U \text { application stage was carried out after } \\
\text { the land parcel measurement stage. } \\
\text { b. Land rights in this case } H G U \text { have a higher } \\
\text { position because they are in the form of } \\
\text { rights than only in the form of business } \\
\text { permits; } \\
\text { c. In Permentan Number } 98 \text { of } 2013 \text { Article } 57 \\
\text { paragraph (2) letter a stated that the } \\
\text { requirements for obtaining } I U P-B, I U P-P \text { or } \\
I U P \text { are photocopies of land title certificates, } \\
\text { so that the } H G U \text { is prior to the existence of } \\
I U P-B, I U P-P \text { or } I U P\end{array}$ \\
\hline 2. & $\begin{array}{l}\text { Land for facilitation of } \\
\text { community } r \text { plantation } \\
\text { development was inside or outside } \\
\text { the } H G U \text { area }\end{array}$ & $\begin{array}{l}\text { Facilitation of community plantation } \\
\text { development was in accordance with MOA } \\
98 / 2013 \text { Article } 15 \text { verse (2) is outside the } H G U \\
\text { area (here it is written } I U P-B, I U P-P \text { or } I U P \text { ) }\end{array}$ \\
\hline 3 & $\begin{array}{l}\text { Whereas the availability of } \\
\text { community land around the } \\
\text { plantation area actually covered } \\
\text { an area of } 20 \% \text {, but the } \\
\text { commodity of the crop was not } \\
\text { the same as the company's crops. }\end{array}$ & $\begin{array}{l}\text { a. In Ministry Regulation of ATR/BPN Number } \\
7 \text { of } 2013 \text { Article } 40 \text { verse (1) letter k that } \\
\text { facilitation of community plantation } \\
\text { development was carried out in accordance } \\
\text { with the business activity license from the } \\
\text { competent technical agency means that it } \\
\text { must be with the same commodity. } \\
\text { b. In a partnership relationship, not only there } \\
\text { was a transfer of capital, but also there was a } \\
\text { transfer of technology. In addition, } \\
\text { partnerships were usually carried out with a } \\
\text { plasma core system, if the commodity was } \\
\text { different then post-harvest activities would } \\
\text { experience difficulties. } \\
\text { c. However, we looked for commodities with } \\
\text { the same commodities as the company even }\end{array}$ \\
\hline
\end{tabular}

${ }^{11}$ Regulation of Ministry of ATR / BPN Number 7 of 2013 concerning Regulations and Procedures for Establishing Business Use Rights Article 7 


\begin{tabular}{|c|c|c|}
\hline & & $\begin{array}{l}\text { though they were outside the plantation } \\
\text { administration area }\end{array}$ \\
\hline 4. & $\begin{array}{l}\text { In the case of land availability, the } \\
\text { community living around the } \\
\text { plantation area did not meet the } \\
20 \% \text { area required by the } \\
\text { company to carry out its } \\
\text { obligation to facilitate community } \\
\text { plantation development. }\end{array}$ & $\begin{array}{l}\text { If the community plantation planned to be } \\
\text { facilitated is not sufficient for } 20 \% \text { of the } H G U \\
\text { area, the facilitation of community plantation } \\
\text { development could be by: } \\
\text { 1. The plasma plantations were taken from the } \\
\text { company's } H G U \text { land with a partnership } \\
\text { agreement that was not detrimental to both } \\
\text { parties. Facilitation of community plantation } \\
\text { development could be carried out through } \\
\text { credit schemes, profit sharing, or other } \\
\text { agreed forms of funding in accordance with } \\
\text { the provisions of laws and regulations. } \\
\text { 2. Local governments, companies and plasma } \\
\text { farmers could also apply for the release of } \\
\text { forest areas into other land uses so that } \\
\text { farmers got cultivation permits from the } \\
\text { Regent. This step was in line with the land } \\
\text { distribution plan in the agrarian reform } \\
\text { scheme. } \\
\text { 3. Plasma Plantation was built outside the } \\
\text { District where the plantation was located if } \\
\text { there was a plasma plantation with the same } \\
\text { commodity. The company was still obliged } \\
\text { to implement CSR so that the community } \\
\text { around the plantation could still get social } \\
\text { benefits/functions from the plantation area. }\end{array}$ \\
\hline
\end{tabular}

2. Facilitation Obstacles for the community plantation development by PT. Pamor Ganda in the Process of Extending its $\mathrm{HGU}$

a. The area of community plasma plantations in the vicinity of $P T$ Pamor Ganda has not yet filled the area of $20 \%$ of the community plantation development facilitation area required for the extension of the $H G U$. The company resolved the problem by handing over a portion of the
$H G U$ area to be developed into a plasma plantation.

b. In Lubuk Mindai village, some of the land that was released by the company were used as village treasury. This was not in accordance with MOA 98/2013 Article 15 verse (3) because the facilitation of community plantation development was for communities around plantations whose participants were communities around the 
plantations who met the requirements according to statutory regulations. But because it has become an agreement between the two parties, it was legally valid.

c. The plasma farmers commited themselves to the company to form a partnership by giving up their land certificate. There was no agreement that stated that the company was not allowed to pledge the certificate. If the company did this it was unfair to the plasma farmer.

\section{CLOSING}

\section{Conclusion}

a. Legal arrangements of the facilitation of community plantation development by plantation companies in Indonesia was still not strictly regulated and there were still multiple interpretations in the regulation because there was no specific regulation regarding this matter.

b. The implementation obstacle by the company was that the area of Plasma farmers around the plantation area has not yet met the $20 \%$ area requirement. PT. Pamor Ganda could meet the requirements for community plantation development by releasing its 114 hectare of $H G U$ area. The area of plasma plantations to facilitate the community plantation development of $P T$. Pamor Ganda covering an area of 455.22 hectares or $20.75 \%$ of the area of land for which the $H G U$ extension was requested, which was 2,192.91 hectares.

\section{Suggestions}

a. Given that the facilitation of community plantation development is mandatory, it is very urgent for the government to make a Government Regulation related to the facilitation of community plantation development, because the current regulations still cannot provide legal certainty and still have multiple interpretations in its implementation.

b. The governor or regents/mayor must accompany and supervise the implementation of facilitation of community plantation development by plantation 
companies in their activities which include planning, fulfilling obligations and business sustainability, so that the implementation of facilitation of community plantation development brings justice and benefits to the community around the plantation and for the company.

c. The partnership agreement between the plantation party and the community is a binding agreement. There should be specific guidelines related to the contents of the agreement in the facilitation of community plantation development, especially in terms of the provisions regarding land certificates that the community guarantees to the company should not be pledged as collateral.

\section{REFERENCES}

A.P Parlindungan, Komentar Atas Undang Undang Pokok Agraria, Bandung : Maju Mundur, 1993.

Achmad Sodiki, Politik Hukum Agraria,Jakarta : Konstitusi Press, 2013.

Amira Inaz Clarissa Pambudi, Kepastian Hukum Kemitraan Petani Penggarap Dengan Perusahaan Perkebunan
Atas Tanah Hak Guna Usaha, Jember : Kementrian Riset, Teknologi dan Pendidikan Tinggi Fakultas Hukum Universitas, 2019.

Ayu Giri Anjani, Perpanjangan Hak Guna Usaha PT. Sunnymas Prima Agung Berdasarkan Peraturan Menteri Negara Agraria Nomor 9 Tahun 1999 di Kabupaten Bintan, Yogyakarta : Fakultas Hukum Universitas Islam Indonesia, 2018.

Bambang Sunggono, Metodologi Penelitian Hukum, Jakarta : Raja Grafindo Persada, 2002.

Boedi Harsono, Hukum Agraria Indonesia, Sejarah Pembentukan UndangUndang Pokok Agraria, Isi dan Pelaksanaannya, Jakarta: Djambatan, 1999.

Boedi Harsono, Hukum Agraria Indonesia, Himpunan Peraturan-Peraturan Hukum Tanah, Jakarta : Djambatan, 2004.

Kartasapoetra, dkk., "Hukum Tanah Jaminan UUPA Bagi Keberhasilan Pendayagunaan Tanah", Jakarta : Rineka Cipta, 1991

Herawan Sauni," Politik Hukum Agraria", Medan : Pustaka Bangsa Press, 2006.

Satjipto, Rahardjo, Ilmu Hukum, Bandung : Citra Adtya Bakti, 2000.

Supriadi, Hukum Agraria, Jakarta : Sinar Grafika, 2015. 